\title{
Pengembangan Mobile Learning Berbasis Program APPYPIE untuk Pembelajaran Fisika
}

\author{
Diah Ratnasari $^{1)}{ }^{*}$, Dewi Oktaviyanti ${ }^{2)}$, Sari Sri Sukmawati ${ }^{3)}$, Eny Setiyawati ${ }^{4)}$ \\ ${ }^{1,2,3,4)}$ Magister Pendidikan Fisika, Universitas Ahmad Dahlan, Yogyakarta
}

Email: diah1707041005@webmail.uad.ac.id

\begin{abstract}
Abstrak: Materi usaha dan energi dianggap mudah bagi siswa, tetapi dalam beberapa penelitian menunjukkan bahwa masih banyak siswa yang mengalami kesulitan. Untuk membantu siswa, diperlukan media pembelajaran yang menarik untuk mempelajari materi tersebut yaitu mobile learning berbasis android. Mobile learning ini berisi kompetensi, materi, soal dan pembahasan, video dan latihan interaktif. Metode penelitian yang digunakan adalah metode Research and Development dengan proses pengembanganya menggunakan model ADDIE (Analysis, Design, Development, Implementation dan Evaluation). Penelitian pengembangan model ADDIE yang dilakukan hanya sampai tahap Development karena tujuan penelitian ini hanya sebatas mengembangkan aplikasi yang valid berdasarkan penilaian validator. Instrumen pengumpulan data terdiri dari lembar validasi ahli media dan lembar validasi ahli materi yang diberikan kepada 2 ahli media dan 2 ahli materi. Hasil validasi ahli media sebesar $90 \%$ dan ahli materi sebesar $84 \%$. Kesimpulan penelitian pengemembangan ini adalah mobile learning berbasis android pada materi usaha dan energi sangat layak digunakan dalam pembelajaran fisika
\end{abstract}

Kata Kunci: Mobile learning, android, pembelajaran fisika

\begin{abstract}
The topic of work and energy are supposed to easy for students, but in some studies mean that there are still many students who experience difficulties. Support students, an exciting learning media is needed to study the material, namely Android-based mobile learning. Mobile learning contains competencies, topic, questions and discussions, videos and interactive exercises. The research method used is the Research and Development method with the development process using the ADDIE model (Analysis, Design, Development, Implementation, and Evaluation). The research on ADDIE model development was given out only to the Development stage because the purpose of this study was limited to developing valid applications based on validator ratings. The instruments of data collection consisted of media expert validation sheets and topic authority validation sheets given to 2 media experts and two topic authorities. Media authority validation results were $90 \%$, and material authorities were $84 \%$. This development research concludes that Android-based mobile learning on work topic and energy is possible to use in physics learning. The next, the researcher will proceed to the implementation and evaluation stage and the dissemination test.
\end{abstract}

Keywords: Mobile learning, android, physics learning.

\section{PENDAHULUAN}

Studi yang dilakukan Kominfo dan UNICEF (2014) bahwa 98 persen dari anak-anak dan remaja yang disurvei tahu tentang internet dan 79,5 persen diantaranya adalah pengguna internet (KEMINFO, 2014). Berdasarkan data tersebut guru harus bisa memanfaatkan perkembangan teknologi sebagai alat bantu dalam proses pembelajaran. Salah satunya adalah penggunaan Mobile learning. Mobile learning dapat digunakan untuk meningkatkan kualitas pembelajaran secara lebih efektif dan efisien (Sulisworo \& Toifur, 2016).
Android dapat digunakan sebagai mobile learning, karena android adalah sistem operasi berbasis Linux yang diperuntukkan untuk mobile device. Android merupakan sistem operasi yang paling diminati di masyarakat karena memiliki kelebihan seperti sifat open source yang memberikan kebebasan para pengembang untuk menciptakan aplikasi (Anggraeni \& R Kustijono, 2013).

Penelitian tentang usaha dan energi memang sudah banyak dilakukan, tetapi belum ada yang membahas secara khusus tanpa melibatkan topik lainnya seperti momentum (Muchoyimah et al., 
2016). Data penelitian menunjukkan bahwa penguasaan konsep fisika pada materi usaha dan energi sangat rendah. 87,7 persen siswa memiliki penguasaan konsep yang salah (Sukma et al., 2016), sehingga pada saat dihadapkan pada soal-soal yang berhubungan dengan konsep dan sedikit perhitungan, sebagian siswa mengalami kesulitan.

\section{METODE}

Penelitian ini merupakan penelitian pengembangan RnD (Research and Development) yang bertujuan untuk menghasilkan suatu produk. Prosedur penelitian ini mengadaptasi model pengembangan ADDIE, yaitu model pengembangan yang terdiri dari lima tahapan yang terdiri dari Analysis (analisis), Design (desain), Development (pengembangan), Implementation (implementasi) dan Evaluation (evaluasi) seperti ditunjukkan Gambar 1(Astuti et al., 2017).

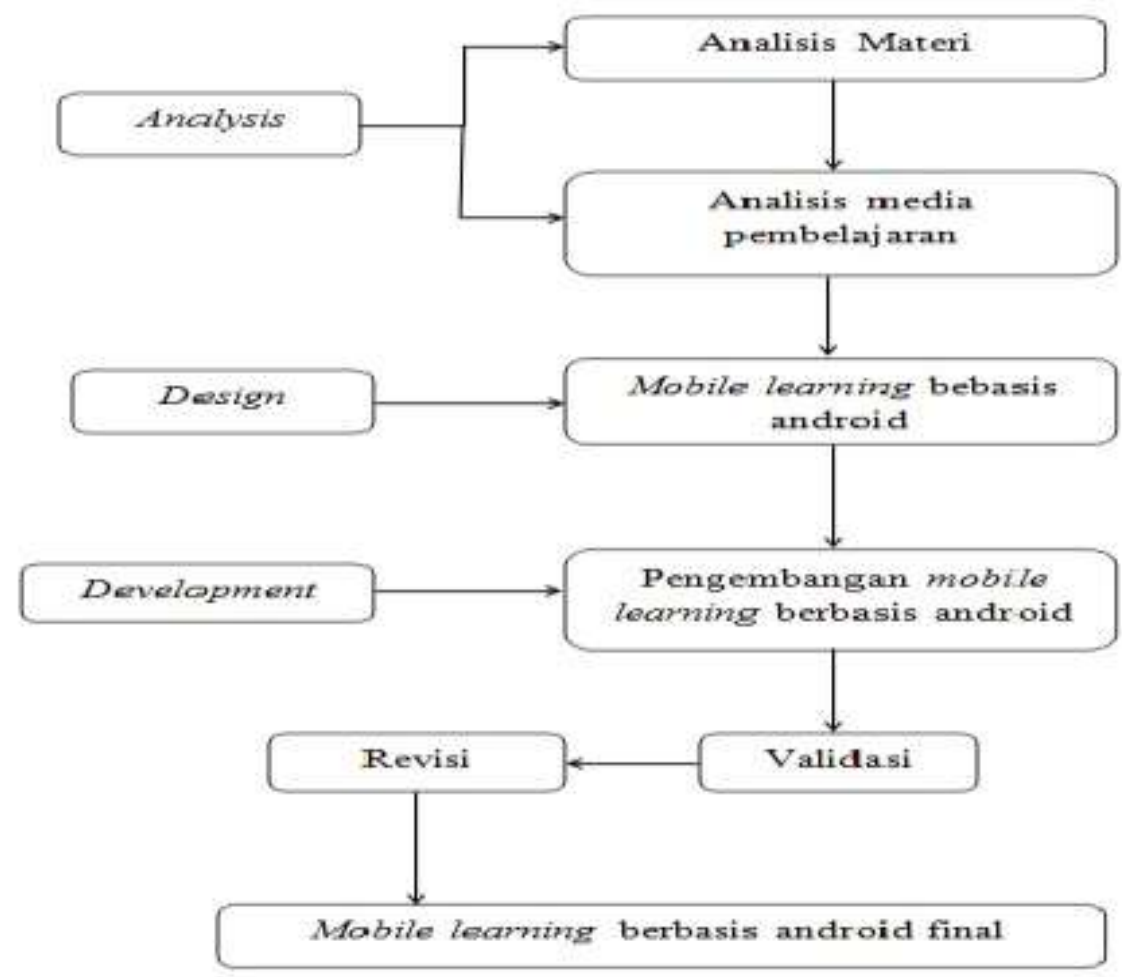

Gambar 1. Tahap pengembangan mobile learning menggunakan metode pengembangan ADDIE

Uji validitas dilakukan oleh validator yang berkompeten yaitu 2 orang validator ahli media dan 2 orang validator ahli materi. Selanjutnya, validator diminta untuk memberikan penilaian secara umum dan saran terhadap mobile learning berbasis android yang dikembangkan.

Penelitian ini menggunakan teknik analisis deskriptif, yakni dengan cara menghitung persentase nilai hasil validasi.

Metode pengumpulan data dalam penelitian ini adalah menggunakan angket. Instrumen untuk ahli

$$
P(s)(\%)=\frac{S}{N} \times 100 \%
$$

Dengan:

$\mathrm{P}=$ Persentase subvariabel $(\%)$

$\mathrm{S}=$ Jumlah skor total subvariabel yang diperoleh

$\mathrm{N}=$ Jumlah skor total maksimum media berhubungan dengan kebahasaan, efek bagi strategi pembelajaran, pengolahan program, dan tampilan. Instrumen untuk ahli materi yang berisikan relevansi materi, pengorganisasian materi, evaluasi, bahasa dan efek bagi strategi pembelajaran. Metode angket digunakan untuk mengukur kualitas serta tanggapan terhadap media pembelajaran yang dikembangkan. Menghitung persentase dari tiap-tiap subvariabel dengan rumus: 
Kriteria dalam mengambil keputusan dalam validasi media pembelajaran mobile learning berbasis android dapat dilihat pada Tabel 1 (Riadi, 2014).

Tabel 1. Kriteria kelayakan mobile learning

\begin{tabular}{ccc}
\hline No & Interval $(\mathrm{P})$ & Kriteria Tingkat Kelayakan \\
\hline 1 & $80 \%-100 \%$ & Sangat Layak/ Sangat Baik/ Sangat Setuju \\
2 & $66 \%-79 \%$ & Layak/ Baik/ Setuju \\
3 & $56 \%-65 \%$ & Kurang Layak/ Kurang Baik/ Kurang Setuju \\
4 & $0-55 \%$ & Tidak Layak/ Tidak Baik/ Tidak Setuju \\
\hline
\end{tabular}

\section{HASIL DAN PEMBAHASAN}

Produk yang dihasilkan dalam pengembangan ini adalah mobile learning berbasis android yang dirancang dan dibuat sendiri oleh peneliti. Penelitian pengembangan model ADDIE yang dilakukan hanya sampai tahap Development karena tujuan penelitian ini hanya sebatas mengembangkan mobile learning yang valid berdasarkan penilaian validator.

Tahap-tahap penelitian ini adalah:

Analysis (analisis) tahap analisis dilakukan dengan analisis materi dan analisis media. Dari tahap analisis materi ditemukan bahwa materi usaha dan energi masih memerlukan media untuk membantu pembelajaran. Dengan mobile learning guru dapat membantu siswa belajar mandiri.

Desain (perancangan) pada tahap desain dilakukan perancangan tampilan aplikasi, materi, gambar, video yang relevan dan angket untuk uji validitas ahli media dan ahli materi.

Development (pengembangan) tahap pengembangan dilakukan pembuatan aplikasi menggunakan appypie, pembuatan latihan interaktif dan validasi ahli media dan ahli materi. Hasil validasi ahli media ditunjukkan pada Tabel 2 dan hasil validasi ahli materi ditunjukkan pada Tabel 3 .

Tabel 2. Hasil Validasi Ahli Media

\begin{tabular}{|c|c|c|}
\hline No & 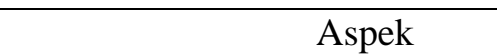 & Persentase \\
\hline 1 & Bahasa & $92 \%$ \\
\hline 2 & Efek bagi strategi pembelajaran & $94 \%$ \\
\hline 3 & Rekayasa Media & $90 \%$ \\
\hline 4 & Tampilan & $85 \%$ \\
\hline & Rata-rata & $90 \%$ \\
\hline
\end{tabular}

Hasil validasi ahli media diperoleh persentase ratarata sebesar 90\%. Berdasarkan analisis ahli media, mobile learning sangat layak digunakan untuk membantu proses pembelajaran fisika pada materi usaha dan energi. Saran dari validator adalah penulisan rumus mengacu pada SI, standarisasi font dan perlunya ditambah contoh soal dan pembahasan.

Tabel 3. Hasil Validasi Ahli Materi

\begin{tabular}{clc}
\hline No & \multicolumn{1}{c}{ Aspek } & Persentase \\
\hline 1 & Relevansi Materi & $79 \%$ \\
2 & Pengorganisasian Materi & $91 \%$ \\
3 & Evaluasi / Latihan soal & $81 \%$ \\
4 & Bahasa & $81 \%$ \\
5 & Efek bagi strategi pembelajaran & $88 \%$ \\
& Rata-rata & $84 \%$ \\
\hline
\end{tabular}

Hasil validasi ahli materi diperoleh persentase rata-rata sebesar $84 \%$. Berdasarkan analisis ahli materi, mobile learning sangat layak digunakan untuk membantu proses pembelajaran fisika pada meteri usaha dan energi. Masukan dari ahli materi adalah perhatikan penulisan kata dan rumus serta aktualisasi konsep usaha energi pada kehidupan sehari-hari.

Penggunaan mobile learning dirasa lebih efektif daripada menggunakan buku karena memudahkan 
siswa belajar dimana saja dan kapan saja serta memudahkan siswa mencari materi untuk mendukung proses pembelajaran (Sulaiman et al., 2017). Selain pembelajaran fisika, Appypie juga dapat digunakan untuk membuat mobile learning pada pembelajaran robotika (Ramansyah, 2018), ekonomi, akuntansi (Pujianto, 2017), sejarah (Mirawati, 2017) dan biologi (Aripin, 2018). Contoh tampilan awal mobile learning ditunjukkan oleh Gambar 2 dan contoh tampilan materi usaha ditunjukkan oleh Gambar 3.

\section{Usaha dan Energi SMA}

\section{$\vdots$}
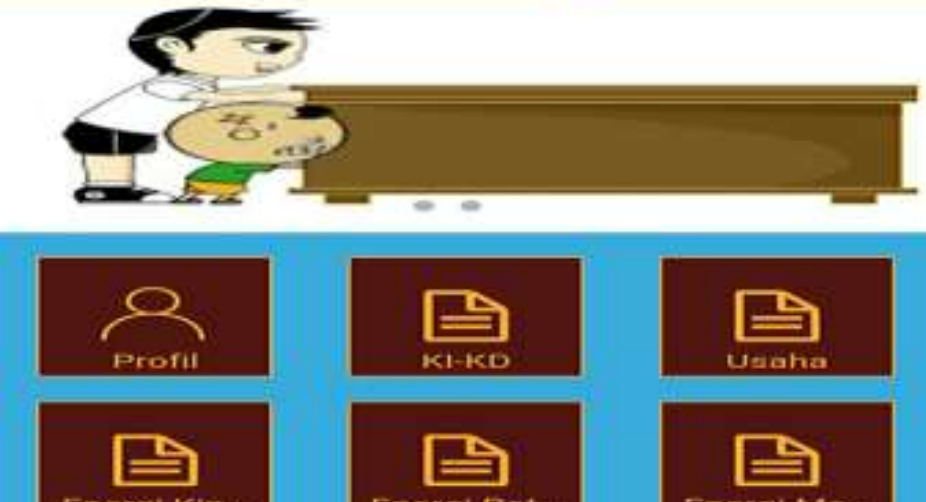

Lenergi Kin..
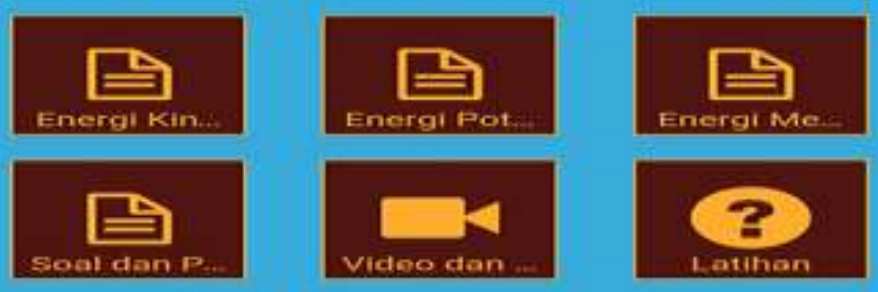

Gambar 2. Tampilan awal mobile learning berbasis android pada materi usaha dan energi.

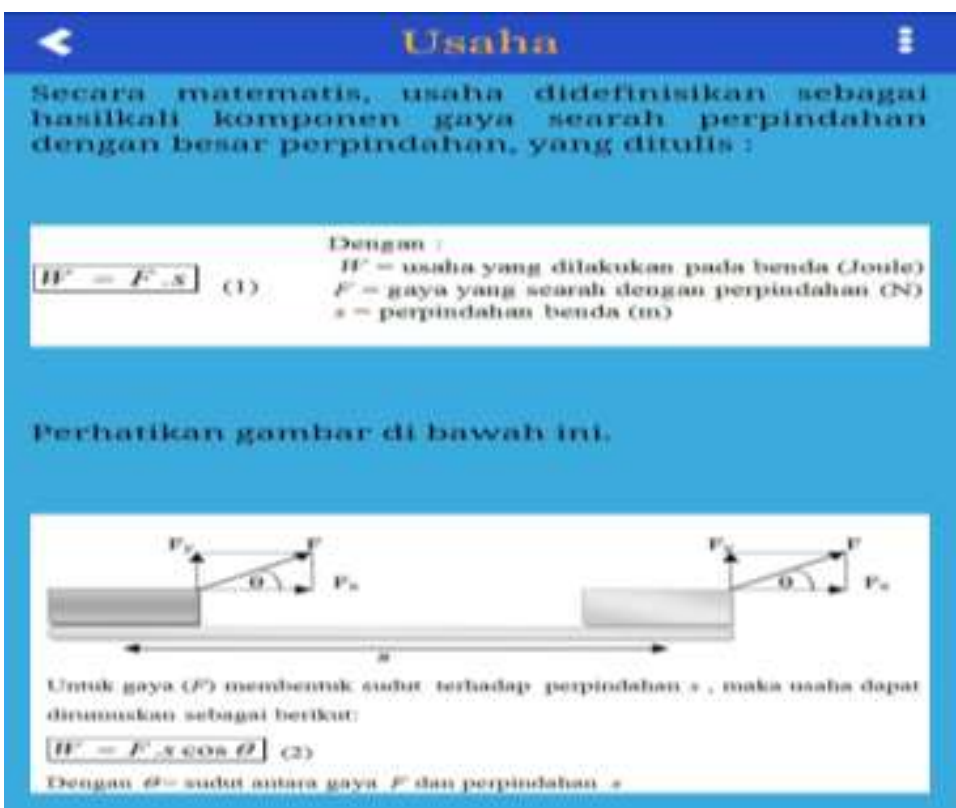

Gambar 3. Tampilan materi usaha.

Peneliti menganalisa beberapa kelebihan mobile learning ini yaitu aplikasi mudah digunakan oleh siswa serta dilengkapi video pembelajaran yang mudah diakses dan terdapat latihan interaktif sehingga siswa dapat mengetahui kebenaran jawaban secara langsung. Selain itu, peneliti juga menemukan kekurangan mobile learning ini, yaitu hanya bisa digunakan apabila menggunakan jaringan 
internet, tidak terhubung dengan playstore, gambar atau tulisan tidak dapat di perbesar, editing hanya dapat dilakukan sebulan sekali apabila menggunakan layanan gratis dan banyak iklan dari penyedia layanan.

Dari hasil uji validasi media (Table 2) medeskripsikan bahwa media pembelajaran dengan menggunaka mobile learning berbasisis appypie mempunyai pengaruh yang tinggi. Hal ini terlihat dari hasil uji validasi memperoleh nilai tertinggi yaitu $94 \%$ berguna bagi strategi pembelajara dan 91\% lebih mudah mengorganisir materi sesuai hasil uji validasi (Tabel 3). Aplikasi ini dianggap sebagai sistem yang memiliki komponen yang saling berhubungan untuk memfasilitasi untuk memperoleh sebuah informasi. Aplikasi yang dihasilkan dalam penelitian ini sudah memiliki persyaratan ini di mana komponen sistem dalam aplikasi adalah fitur yang tersedia dengan informasi masing-masing sesuai dengan judul yang diberikan kepada aplikasi sebagai batas sistem. Dalam aplikasi appypie dilengkapi pula dengan fitur Kirim pesan ke pengguna, Persyaratan Wallpaper Sistem JDK, Multi unggah untuk media, Obrolan (Gupta et al., 2016).

Kemudian dengan menggunakan mobile learning berbasis appype memudahkan guru dan siswa karena didukung platform Android, Mac OS, Windows Phone, Blackberry, dan HTML. Selain itu, dengan menggunakan sofware appypie dapat menyimpan semua gambar konten, grafik, teks, audio, dan video untuk kebutuhan aplikasi. Aplikasi tampilan juga dapat diakses di web di alamat: (https: //snappy.appypie.com/user/app/user/5fff4f86d579)

(Fayanto et al., 2019; Muslimin et al., 2017).

Selanjutnya, dengan menggunakan mobile learning siswa dengan dapat mengakses pembelajaran dengam mudah. Hal ini diperkuat dari ungkapan (Ibrahim et al., 2016; Irawan \& Ery Tri Djatmika, 2018) yang mengemukakan bahwa pembelajaran mobile peserta didik dapat mengakses pelajaran dan tugas di mana saja dan kapan saja sementara untuk guru, pembelajaran bergerak dapat membantu mengunggah bahan ajar, menentukan diskusi dan menerima tugas siswa secara elektronik. Sedangkan Temuan penelitian ini juga didukung oleh hasil penelitian yang menunjukkan perkembangan media memiliki dampak positif dalam meningkatkan hasil belajar (Ekawarna et al., 2018) dan meningkatkan kualitas pembelajaran belajar (Onyenemezu \& Olumati, 2014).

Peneliti menganalisa beberapa kelebihan mobile learning ini yaitu aplikasi mudah digunakan oleh siswa serta dilengkapi video pembelajaran yang mudah diakses dan terdapat latihan interaktif sehingga siswa dapat mengetahui kebenaran jawaban secara langsung (Herawati et al., 2019). Selain itu, peneliti juga menemukan kekurangan mobile learning ini, yaitu hanya bisa digunakan apabila menggunakan jaringan internet, tidak terhubung dengan playstore, gambar atau tulisan tidak dapat di perbesar, editing hanya dapat dilakukan sebulan sekali apabila menggunakan layanan gratis dan banyak iklan dari penyedia layanan.

Selain itu, temuan ini memiliki dampak bagi perancang perangkat lunak pendidikan khusunya dibidang pembelajaran fisika. Desain dan pengembangan instruksional harus memasukkan elemen teknologi seluler dalam produk sehingga dapat menjadikannya lebih efektif, menarik, dan interaktif. Masa depan menggunakan teknologi untuk mengajar fisika akan menjadi kelanjutan dari tren baru-baru ini: peningkatan portabilitas dalam akses ke instruksi dan peningkatan peluang untuk interaksi, termasuk interaksi siswa dengan materi dan dengan instruktur dan siswa lainnya. Secara umum mobile learning berbasis Appypie untuk pembelajaran fisika layak digunakan dan diimplementasikan dalam pembelajaran fisika di sekolah.

\section{KESIMPULAN}

Dari hasil penelitian yang telah dilakukan dapat diambil kesimpulan bahwa, mobile learning berbasis android telah berhasil dibuat. Mobile learning ini termasuk dalam kategori sangat baik sebagai media pembelajaran. Berdasarkan data validasi ahli media diperoleh persentase rata-rata sebesar $90 \%$ dengan kategori sangat layak, dan validasi ahli materi diperoleh persentase $84 \%$ dengan kategori sangat layak, sehingga mobile learning berbasis android pada materi usaha dan energi sudah sangat layak untuk digunakan dalam pembelajaran fisika.

\section{DAFTAR PUSTAKA}

Anggraeni, R. D., \& R Kustijono. (2013). Pengembangan media animasi fisika pada materi cahaya dengan aplikasi flash berbasis android. Jurnal Pendidikan Fisika Dan Aplikasinya, 31(1), 11-18.

Aripin, I. (2018). Konsep dan aplikasi mobile learning dalam pembelajaran biologi. Journal Bio Education, 3(1), 01-09.

Astuti, I. A. D., Sumami, R. A., \& Saraswati, D. L. (2017). Pengembangan media 
pembelajaran mobile learning berbasis android. Jurnal Penelitian dan Pengembangan Pendidikan Fisika, 3(1), 57-62.

Ekawarna, Nasori, A., \& Riyadi, R. (2018). The Effectiveness of android-based learning media with appypie toward indonesian economics subject. International Journal of Engineering \& Technology, 7(3), 287288.

Fayanto, S., Kawuri, M. Y. R. T., Jufriansyah, A., Setiamukti, D. D., \& Sulisworo, D. (2019). Implementation E-learning based moodle on physics learning in senior high school. Indonesian Journal of Science and Education, 3(2), 93.

Gupta, S. G., Chanekar, P. A., Lodhe, S. J., \& Parekar, P. P. (2016). Comparative study of online app designing tools. International Journal of Research In Science \& Engineering, Techno-Xtreme 16, 669-674.

Herawati, R., Sulisworo, D., \& Fayanto, S. (2019). The development of learning videos on powtoon-based work and energy topics to support flipped classroom learning. IOSR Journal of Research \& Method in Education (IOSR-JRME), 9(4), 51-58.

Ibrahim, A., Elfeky, M., Saleem, T., \& Masadeh, Y. (2016). The Effect of Mobile Learning on Students 'Achievement and Conversational Skills.International Journal of Higher Education, 5(3), 20-31.

Irawan, C., \& Ery Tri Djatmika. (2018). Developing instructional media mobile learning based android to improve learning outcomes. Jurnal Pendidikan Bisnis Dan Manajemen, 4(3), 117-124.

KEMINFO. (2014). Riset Kominfo dan UNICEF Mengenai Perilaku Anak dan Remaja Dalam Menggunakan Internet. In KEMINFO.

Mirawati, A. (2017). Pengembangan Media Pembelajaran Aplikasi Android "Batik Jonegoroan" untuk Memperkuat Nasionalisme dan Pendidikan Karakter dalam Pembelajaran Sejarah tingkat SMA. Universitas Negeri Malang.
Muchoyimah, S., Kusairi, S., \& Mufti, N. (2016). Identifikasi Kesulitan Siswa pada Topik Usaha dan Energi. Semnas Pendidikan IPA Pascasarjana Universitas Negeri Malang, 1, 492-500.

Muslimin, M. S., Nordin, N. M., \& Mansor, A. Z. (2017). The design and development of mobieko: a mobile educational app for microeconomics modulE. Malaysian Journal of Learning and Instruction, Special Issues 2017, 221-255.

Onyenemezu, C. E., \& Olumati, E. . (2014). Educational media and technology: a panacea for effective teaching and learning among trainee adult educators in university of port harcourt. British Journal of Education, 2(3), 75-81.

Pujianto, N. (2017). Pengembangan media pembelajaran berbasis appypie materi siklus akuntansi perusahaan jasa kelas $X$ akuntansi di SMK Negeri 1 Pogalan. Unversitas Negeri Malang.

Riadi, B. S. (2014). Pengembangan media animasi dan teka-teki silang berbasis android tentang gelombang bunyi untuk sekolah menengah atas. Universitas Ahmad Dahlan.

Sukma, F. B. B., Koes, S., \& Kusairi, S. (2016). Identifikasi penguasaan konsep siswa pada materi usaha dan energi. Prosiding Semnas Pend. IPA Pascasarjana UM, 1, 208-212.

Sulaiman, M. S., Nordin, N. M., Mansor, A. Z., \& M M yunus. (2017). The Design And Development of MobiEko: A Mobile educational app for microeconomics module. Malaysian Journal of Learning and Instruction, Special Issue, 221-225.

Sulisworo, D., \& Moh. Toifur. (2016). The role of mobile learning on the learning environment shifting at high school in Indonesia. International Journal Mobile Learning and Organization, 10(2), 159170.

W Ramansyah. (2018). Pengembangan multimedia pembelajaran interaktif berbasis appypie pada bahan pengenalan robotika dasar. Prosiding Seminar Nasional Kaluni, 1, 72-79. 